Section Editors

David C. Spencer, MD

Steven Karceski, MD

Deniz Erten-Lyons, MD

\title{
When should patients with Alzheimer disease stop driving?
}

Patients with Alzheimer disease (AD) usually have problems with memory. During their illness, they may also start having problems with making good decisions. They may begin having difficulty with interpreting things that they see and may react slower. They may have trouble following directions and may get lost. These abilities are all necessary for safe driving. Therefore, all patients with $\mathrm{AD}$ will have to stop driving at some point during their illness. Patients with advanced AD should not be driving at all. However, it is often not clear when a person with mild symptoms of AD should stop driving.

In this issue of Neurology ${ }^{\circledR}$, a study by Dr. Ott and coauthors ${ }^{1}$ examined driving skills in patients with early AD. The study goal was to understand the changes in driving skills over time in patients with AD. They wanted to find out when a person with AD starts having trouble that could interfere with safe driving. They also wanted to understand what other factors might lead to worsening driving skills in patients with AD.

HOW WAS THE STUDY DONE? The authors followed 84 patients with very mild and mild AD. A rating scale called the Clinical Dementia Rating Scale was used to determine whether a patient had very mild or mild AD. The researchers did not include patients with more advanced dementia. Patients had on-road driving tests every 6 months. Patients would "fail," meaning they were not safe drivers anymore, if one of three things happened: (1) if the patient could not pass the on-road driving test; (2) if the patient had an at-fault car accident; and (3) if the patient's dementia became worse than mild.

The authors also included 45 elderly people who did not have AD. This group served as a comparison group. This group had an on-road driving test when they entered the study. About half also had retesting at 18 months. The authors did not include people with other conditions that could affect driving skills. Examples of such conditions are amputations or vision problems.

WHAT WERE THE MAIN FINDINGS? Results of the first on-road driving test. Overall, the majority of patients with very mild or mild $\mathrm{AD}$ were able to pass the first on-road driving test. All research participants without $\mathrm{AD}$ passed. More patients with mild AD failed compared to those with very mild $\mathrm{AD}$.

Results of follow-up. All participants showed a decline in driving skills. Patients with mild AD showed the fastest decline. Patients with mild AD became unsafe drivers after an average of 11 months. Patients with very mild AD remained safe drivers for an average of 1.7 years.

What else was associated with unsafe driving? $\mathrm{AD}$ patients who were over 76 years old or had less than 14 years of education were more likely to be unsafe drivers.

Comparison of crashes. Drivers with dementia had fewer car crashes than drivers in the healthy elderly comparison group. This difference was explained by the fact that many dementia patients reduced or stopped their driving during the course of the study.

WHY IS THIS STUDY IMPORTANT? According to some current guidelines, patients with even mild AD should stop driving. ${ }^{2}$ However, in the current study, most patients with mild AD were able to pass the on-road driving test. They remained safe drivers for several months. This study also suggests that among patients with $\mathrm{AD}$, those who are older and have less education are more likely to become unsafe drivers faster.

WHAT IS THE BOTTOM LINE? Patients with AD will have to stop driving at some point during their illness. In the early stages, an individual's driving ability should ideally be tested by an onroad driving test. Driving skills should be reassessed at least every 6 months. Families and caregivers need to observe for any warning signs that may indicate unsafe driving. Patients who have more advanced dementia (moderate to severe) should not be driving at all.

WHAT FUTURE RESEARCH IS NEEDED? Onroad driving tests are expensive and not available everywhere. Further research is needed to come up with tests that providers can use in the office to determine whether a patient is able to drive safely. Also, it is not clear how well on-road driving tests actually show how an individual drives in real traffic. Future research is needed to help us understand this better. 
WHAT IS DEMENTIA? Dementia means having problems with memory or thinking. People with dementia cannot carry out their day-to-day functions without help.

WHAT IS ALZHEIMER DISEASE? Alzheimer disease (AD) is the most common cause of dementia in the United States.

In $\mathrm{AD}$, clusters of proteins accumulate in the brain. These lead to destruction and loss of brain cells. The changes in the brain start many years before a person actually shows symptoms.

WHAT ARE THE SYMPTOMS OF AD? The earliest symptom usually is loss of recent memory or trouble coming up with words. Other symptoms include misplacing things, not being able to do familiar tasks, confusion about dates, not recognizing places or people, change in mood or behavior, and losing interest in doing things.

WHY DOES A PATIENT WITH AD HAVE PROBLEMS DRIVING? As a result of changes in the brain caused by the disease, a person with $\mathrm{AD}$ may exhibit problems with reacting fast, making decisions, perception, multi-tasking, and memory. All of these can result in impaired driving.

WHAT ARE SOME OF THE WARNING SIGNS THAT A PATIENT WITH AD IS STARTING TO HAVE TROUBLE DRIVING? The following are some warning signs indicating that a patient with $\mathrm{AD}$ may be having trouble with driving ${ }^{3}$ :

- Not remembering the location of familiar places, having a hard time with new directions

- Not observing traffic signs

- Mistaking the gas pedal for the brake

- Not driving at appropriate speeds

- Stopping inappropriately (for example, at a green light)

- Becoming confused and overwhelmed while driving (for example, finding traffic signals confusing)

- Making poor or slow decisions while driving

- Having difficulty making left turns

- Noticing that other drivers frequently honk

- Dents and scrapes on the car
- Becoming angry and frustrated when driving

- Drifting out of one's lane

- Not looking when moving from one lane to another

- Taking much longer to get to places

Family and friends should ride frequently with the $\mathrm{AD}$ patient in order to look for any of the warning signs that the patient may be starting to have trouble with driving.

WHAT ARE SOME WAYS TO HELP A PATIENT WITH AD GIVE UP DRIVING? Since all patients with $\mathrm{AD}$ will have to stop driving at some point, it is important to start talking about this early on. Reducing one's driving gradually over time works better for most patients. For example, a patient with early $\mathrm{AD}$ can start driving only during the day, or can start avoiding highways, or can drive only in familiar places and short distances.

It is important to try to help a person stay independent after he or she gives up driving. Family and friends can be a big help. They can provide rides to the patient. They can also help in planning other forms of transportation. Some other options to get to places are using taxis, shuttles, or public transportation. Information on transportation for the elderly may be obtained from the local Agency on Aging and the National Transit Hotline.

WHAT IF THE PATIENT WITH AD REFUSES TO STOP DRIVING? Sometimes patients with AD may not be aware of the problems they are having. In these cases they may refuse to stop driving. It may be helpful to have the health care provider, in addition to the family members, discuss driving. It may also help to get a prescription saying "do not drive" from the doctor. If these measures fail, caregivers may control access to the car. Ways to do this include hiding the car keys, disabling the car, or parking the car elsewhere. If these fail, caregivers may request that the Department of Motor Vehicles (DMV) perform a driving test on the person with $\mathrm{AD} .^{3}$

WHERE CAN A PATIENT WITH AD GET ONROAD DRIVING TESTING DONE? While some state agencies (such as the local DMV) may provide 
driving tests, you may also obtain fee-for-service assessments. A list of therapists who provide such assessments may be obtained from your local Alzheimer's Disease Association chapter or the American Occupational Therapy Association.

\section{FOR MORE INFORMATION}

Alzheimer's Association www. alz.org

American Geriatrics Society www.americangeriatrics.org American Occupational Therapy Association www1.aota.org

National Transit Hotline 1-800-527-8279

\section{REFERENCES}

1. Ott BR, Heindel WC, Papandonatos GD, et al. A longitudinal study of drivers with Alzheimer disease. Neurology 2008;70:1171-1178.

2. Dubinsky RM, Stein AC, Lyons K. Practice parameter: risk of driving and Alzheimer's disease (an evidencebased review): report of the Quality Standards Subcommittee of the American Academy of Neurology. Neurology 2000;54:2205-2211.

3. Alzheimer's Association. Living with Alzheimer's: Safety Issues: Driving. Available at: http://www.alz. org/living_with_alzheimers_driving.asp\#2. Accessed January 15, 2008. 


\section{Neurology}

\section{When should patients with Alzheimer disease stop driving? \\ Deniz Erten-Lyons \\ Neurology 2008;70; 45 -e47 \\ DOI 10.1212/01.wnl.0000310816.24704.d0}

\section{This information is current as of May 22, 2008}

\section{Updated Information \&} Services

References

Permissions \& Licensing

Reprints including high resolution figures, can be found at: http://n.neurology.org/content/70/14/e45.full

This article cites 2 articles, 2 of which you can access for free at: http://n.neurology.org/content/70/14/e45.full\#ref-list-1

Information about reproducing this article in parts (figures,tables) or in its entirety can be found online at:

http://www.neurology.org/about/about_the_journal\#permissions

Information about ordering reprints can be found online: http://n.neurology.org/subscribers/advertise

Neurology ${ }^{\circledR}$ is the official journal of the American Academy of Neurology. Published continuously since 1951, it is now a weekly with 48 issues per year. Copyright. All rights reserved. Print ISSN: 0028-3878. Online ISSN: 1526-632X.

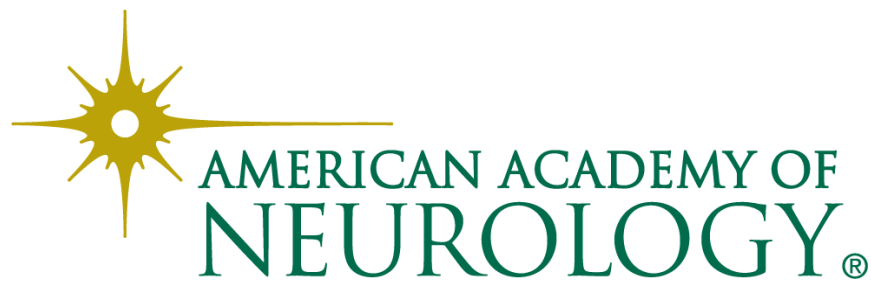

